\title{
Stem Cell Transplant Recipient
}

National Cancer Institute

\section{Source}

National Cancer Institute. Stem Cell Transplant Recipient. NCI Thesaurus. Code C159660.

An individual receiving a stem cell transplant. 